\title{
Forensic Entomology- Insects Role in Criminal and Civil Laws
}

\author{
A. Appala Raju* \\ Agricultural College, Bapatla, Acharya N G Ranga, Agricultural University, \\ Guntur, Andhra Pradesh, India \\ *Corresponding author
}

A B S T R A C T

Keywords

Forensic, Insects, Criminal, Civil, laws

Article Info

Accepted:

17 December 2018

Available Online:

10 January 2019

\section{Introduction}

The "forensic" word is derived from Latin "forensic" means 'in open court, public', from forum. Forensic science is the application of science to criminal and civil laws. The forensic application of entomology has a long, although sporadic, written history reaching back to $13^{\text {th }}$ century China, then more recently, more than a century ago, associated with medical professionals and pathologists interested in entomology in France and Canada (American Board of Forensic Entomology, 1997). In India, the earliest study on this subject is believed to be by Mackenzie in Calcutta (Indian Medical Gazette, 1889) where observations on dead bodies about the times of appearance of eggs and maggots Though not much record is available about this study in the contemporary literature.

The idea of using insect activity as a means to catch criminals is not new. In the Yuan Dynasty (around 1300 A.D.), a Chinese mandarin named Sung T'zu made the first recorded observations of the usefulness of insects in solving crimes. Sung, was the "forensic authority" of the day. He wrote in one of the earliest criminology works, entitled Washing Away of Wrongs, that "during the hot months, if maggots have not yet appeared at the nine orifices [of the body], but they have appeared at the temples, hairline, rib cage, or belly, then these parts have been injured." 


\section{Why are insects used in forensic science?}

- In most seasons and environments, insects colonize a dead body almost immediately after death.

- Their rate of development and species dynamics over time can be used to accurately determine time since death.

- After 72 hours, entomological evidence is the most accurate method to determine the elapsed time since death.

\section{The history of forensic entomology}

- $1^{\text {st }}$ recorded use: $13^{\text {th }}$ century China

- Became quite commonly used in Europe throughout the $20^{\text {th }}$ century

- Popularity increased in North America in the 1970's

- Today: used quite extensively and commonly in homicide investigations.

What can insects infer us relating to clue for crime

- Post mortem interval

- Whether the body was moved after death

- Whether the body was disturbed

- Presence and position of wound sites

- If the victim used drugs or was poisoned

- Length of time of abuse or neglect in living victims

\section{The significance of forensic entomology}

Forensic Entomology is used to determine time since death (the time between death and corpse discovery). The other information may include i. Movement of the corpse, ii. Manner and cause of death, iii. Association of suspects with the death scene and iv. Detection of toxins, drugs, or even the DNA of the victim through analysis of insect larvae. Forensic Entomology is the use of the insects and other arthropods that feed on decaying remains to aid legal investigations and mainly involves three major applications:
1. Identification of insects at various stages of their life cycle, such as eggs, larva, and adults

2. Collection and preservation of insects as evidence.

3. Testifying in court to explain insect-related evidence found at a crime scene

Practical use of insects or arthropods in solving crime led to the development of a separate branch of science, now-a-days known as Forensic Entomology. Forensic is the use of scientific techniques to solve crimes, and is used to describe the work of scientists who examine evidence in order to help the police solve crimes (Anderson, 1996). The carcass decomposition of pig has reported 140 arthropod taxa out of which $83 \%$ were insects. These insects were attracted in the first instance to the body fluids oozing from natural opening and to blood or serum escaping from the wounds. Determining an estimate for the postmortem interval or PMI (the time between death and the discovery of the body) using factors such as insect evidence, weather conditions, location and condition of the body, etc often focuses on violent crimes.

\section{Insect used in forensic entomology}

The overwhelming majority of the insects used in forensic studies are the flies and beetles. Dipteran families namely Calliphoridae, Sarcophagidae, Muscidae, Sepsidae, Sphaeroceridae, Piophilidae, Phoridae and Coleopteran families namely Histeridae, Staphylinidae, Silphidae, Cleridae, Dermestidae, Tenebrionidae predominate the scene (Goff and Fly, 2000). According to Smith (1986) the carrion insects are grouped into necrophagous, coprophages, dermatophages, predaceous, parasitic and adventives or incidental species on the basis of their food preferences which reflects their ecological role. From the insect carrion the information on post mortem interval, whether 
the body was moved after death, whether the body was disturbed, presence and position of wound sites, if the victim used drugs or was poisoned and length of time of abuse or neglect in living victims can be obtained.

The developmental stages of serial wave of flies that colonizes carrion and their key indication of time of death are depicted in Table 1. The important environment factors in corpse decay briefing the time of death was summarised in Table 2.
Stages of decomposition fueled by insect activity

Developmental data are simply data pertaining to the duration of development of immature stages recorded at different temperatures

1. Fresh

2. Bloat

3. Decay

4. Post-decay

5. Dry (skeletal)

\begin{tabular}{|l|l|l|}
\hline Stage & & Description \\
\hline Initial or fresh & $:$ & $\begin{array}{l}\text { The cadaver appears fresh externally but is decomposing internally } \\
\text { due to the activities of bacteria present before death (0-4 days) }\end{array}$ \\
\hline Bloat & $:$ & $\begin{array}{l}\text { The cadaver is swollen by gas produced internally, accompanied by } \\
\text { the odour of decaying flesh (4-10) }\end{array}$ \\
\hline Decay & $:$ & $\begin{array}{l}\text { Flesh of creamy consistency, with exposed body parts black. Body } \\
\text { collapses as gases escape. Fluids drain from body. Odour of decay } \\
\text { very strong (10-20 days) }\end{array}$ \\
\hline Post decay & $:$ & $\begin{array}{l}\text { Cadaver drying out. Some flesh remains at first; chessy odour from } \\
\text { butyric acid (20-50 days) }\end{array}$ \\
\hline Dry & $:$ & $\begin{array}{l}\text { Cadaver almost dry; slow rate of decay. May mummify (50-365 } \\
\text { days). }\end{array}$ \\
\hline
\end{tabular}

\section{Other applications of forensic entomology}

- Damage to structures, Clothing, foodstuffs

- Location of wounds on a corpse

- Linking suspect to scene of crime

- Source of contraband

- Type of insects can trace vehicle movement

- Presence of drugs in corpse

Case studies relating to Forensic Entomology

\section{Case study 1. Estimation of PMI (Arbois, 1985)}

This was the first case to determine PMI in forensic entomology by Dr. Arbois

A mummified body of a child was found by a owner in an apartment after a week of moving into the apartment
The court wants to know whether the new owner was to suspect on the old one

Dr. Arbois based on the life cycle of necrophagous flies found on the body.

He found that the death occurred two years before and the old owner was found to be guilty of the murder. 
Table.1 Developmental stages of flies colonizes carrion

\begin{tabular}{|c|c|c|c|c|}
\hline $\begin{array}{c}\text { Days after } \\
\text { death }\end{array}$ & $\begin{array}{c}\text { House } \\
\text { fly }\end{array}$ & $\begin{array}{c}\text { Blow } \\
\text { fly }\end{array}$ & $\begin{array}{c}\text { Flesh } \\
\text { fly }\end{array}$ & $\begin{array}{c}\text { Skipper } \\
\text { fly }\end{array}$ \\
\hline $\mathbf{1}$ & & EGG & LARVAE & \\
\hline $\mathbf{2}$ & EGG & LARVAE & LARVAE & \\
\hline $\mathbf{3}$ & EGG & LARVAE & LARVAE & \\
\hline $\mathbf{4}$ & LARVAE & LARVAE & LARVAE & \\
\hline $\mathbf{5}$ & LARVAE & LARVAE & LARVAE & EGG \\
\hline $\mathbf{6}$ & LARVAE & LARVAE & LARVAE & EGG \\
\hline $\mathbf{7}$ & LARVAE & LARVAE & LARVAE & LARVAE \\
\hline $\mathbf{8}$ & LARVAE & LARVAE & LARVAE & LARVAE \\
\hline $\mathbf{9}$ & LARVAE & LARVAE & LARVAE & LARVAE \\
\hline $\mathbf{1 0}$ & LARVAE & LARVAE & PUPA & LARVAE \\
\hline $\mathbf{1 1}$ & LARVAE & LARVAE & PUPA & LARVAE \\
\hline $\mathbf{1 2}$ & PUPA & LARVAE & PUPA & LARVAE \\
\hline $\mathbf{1 3}$ & PUPA & LARVAE & PUPA & PUPA \\
\hline $\mathbf{1 4}$ & PUPA & PUPA & PUPA & PUPA \\
\hline $\mathbf{1 5}$ & PUPA & PUPA & PUPA & PUPA \\
\hline $\mathbf{1 6}$ & PUPA & PUPA & PUPA & PUPA \\
\hline $\mathbf{1 7}$ & PUPA & PUPA & PUPA & PUPA \\
\hline $\mathbf{1 8}$ & & PUPA & PUPA & PUPA \\
\hline $\mathbf{1 9}$ & & PUPA & ADULT & ADULT \\
\hline $\mathbf{2 0}$ & & PUPA & & \\
\hline $\mathbf{2 1}$ & & ADULT & & \\
\hline
\end{tabular}

Table.2 Time of death can be broadly estimated up to about 36 hours

\begin{tabular}{|c|c|c|}
\hline Temperature & Stiffness & Time of Death \\
\hline Warm & Not stiff & Death less than $3 \mathrm{~h}$ \\
\hline Warm & Stiff & Between $3-8 \mathrm{~h}$ \\
\hline Cold & Stiff & Between $8-36 \mathrm{~h}$ \\
\hline Cold & Not stiff & More than $36 \mathrm{~h}$ \\
\hline
\end{tabular}

Case study 2 (Benecke, 1995)

A partly putrefied caukasian woman corpse found on 6 November, 1995 with only few adult flies found on the corpse. After removal of corpse, the room was disinfected using lysoformin.

At the end of febrauary, 1996, maggots were found in the neighboring houses. The maggots were found to be of blow fly larvae i.e., Calliphora vomirorva

The unusual appearance of blow flies after 3 months after disinfection is due to the low temperature prevailed at the time of disinfection and maggots have undergone diapauses in the crevices of the floor and escaped disinfection by the chemicals 
From the laboratory rearing studies of the maggots collected from the neighbouring houses estimated the number of generations of blow flies revealed that the death occurred on 13/9/95 i.e., during September, two months prior to the recovery of the body.

\section{Case study 3 (Benecke, 1995)}

Youngsters who was a drug addict was found dead and his body was found in woods early in the morning at $7 \mathrm{AM}$ and it was not there the previous night until $10 \mathrm{PM}$.

The autopsy report stated that the death occurred due to drugs.

The maggots of Lucilia and Calliphora were found in corpse.

The calliphora does not lays eggs during night. Hence, the forensic reports came to a conclusion that the body was shifted to the woods from elsewhere.

The friends of the body shifted to the body to woods as they wants to escape the enquiry.

In conclusion, science, Forensic entomology is an emerging field in forensic sciences, where the insects feeding on corpses are studied. It has become an important tool in criminal investigations. In the present scenario, the role of forensic odontologists is not confined to hard tissue examination alone. Increased instances of forensic odontologists being involved in criminal investigations, as part of the forensic team, have necessitated the need for an increase in awareness of emerging sciences like forensic entomology and its applications in forensics.

\section{References}

Aggarwal AD. 2005. Estimating the postmortem interval with the help of entomological evidence (thesis submitted to the Baba Farid University of Health Sciences, Faridkot, 2005 for $\mathrm{MD}$ in Forensic Medicine). Anil Aggrawal's Internet Journal of Forensic Medicine and Toxicology, Vol, 6(2) Pp. 350-380.

American Board of Forensic Entomology. Welcome to the World of Forensic Entomology. [Available: World Wide Web, http://www.missouri.edu/cafnr/ entomology/ index.html. 1997.

Benecke M.1998. Six Forensic Entomology Cases: Description and Commentary. Journal of Forensic Sciences 1998; 43(4): 797-805.

Byrd J H and Castner J L. 2000. Forensic Entomology: The Utility of Arthropods in Legal Investigations. CRC Press, Florida. 1st ed.; Pp. 1-220.

Goff M L and Fly. 2000. A for the Prosecution. Harvard University Press, Cambridge, $2^{\text {nd }}$ edn, Pp. 1-225.

Smith K G V. 1986. A manual of Forensic Entomology. The Trustees of British Museum (Natural History), London. 1986; Pp. 1-205.

\section{How to cite this article:}

Appala Raju, A. 2019. Forensic Entomology- Insects Role in Criminal and Civil Laws. Int.J.Curr.Microbiol.App.Sci. 8(01): 2479-2483. doi: https://doi.org/10.20546/ijcmas.2019.801.262 